EVS28

KINTEX, Korea, May 3-6, 2015

\title{
Policy strategies for an emergent technology: lessons from the analysis of EV-policy in 8 North- European countries
}

\author{
Dr. Martijn van der Steen ${ }^{1}$ \\ R.M. van Schelven ${ }^{2}$ \\ Dr. P. Van Deventer MPA ${ }^{3}$ \\ Prof. Dr. M. Van Twist ${ }^{4}$ \\ R. Kotter M.A. ${ }^{5}$
}

\begin{abstract}
This paper presents data from a comparative study of EV-policies in 8 different North-European countries, that maps out all of the policies of these countries (and a range of regions and cities) that target passenger vehicles (PHEV and BEV), chargers (home, private, public; level 1-3), and policies that target the emobility eco-system or supporting network, in time-period 2012-2014. The main findings are that 1) there is wide variance of policies put out by the different countries, 2) these policies are hardly part of a coherent policy-strategy, and 3) mainly address the introduction of e-mobility as an issue of "piling up" enough incentives to overcome early market problems (e.g. high costs, reticent customers, slow adaptation of regulation). Most countries we studied were able to meet short-term policy-ambitions, and some have even surpassed those ambitions; Netherlands and Norway for instance are ahead of their targets, both in numbers of vehicles and chargers. However, if we compare the currently applied policies to the medium- and longer term ambitions, these policies are hardly viable. Therefore, argue for alternative policy strategies that do not "pile up" incentives, but look at "mixes" of policies that instigate a self-reinforcing loop in the adoption to EV's.

\footnotetext{
${ }_{1}^{1}$ Corresponding Author: Netherlands School of Public Administration (NSOB), steen@,nsob.nl.

2 KWINK Group Consultants rvanschelven@kwinkgroep.nl.

3 Governor's Office of Planning and Research, State of California \& Province of North-Holland, The Netherlands petervandeventer@gmail.com.

${ }^{4}$ Erasmus University Rotterdam, vantwist@ffsw.eur.nl

5 R. Kotter, M.A., Northumbria University, Newcastle upon Tyne, richard.kotter@northumbria.ac.uk
} 


\section{Introduction}

All over the world, governments attempt to support the transition to e-mobility. The introduction of electric driving is a complex and unpredictable process that is not likely to occur all by itself. The incumbent market structure benefits continuation of regular cars, and consumers are not yet familiar with e-mobility. Furthermore, EV's require a substantial investment by consumers. Due to expensive battery packs sales-price of EVs are higher than those of comparable regular cars. Also, the residual value and life cycle of the batteries is uncertain, as are benefits to be gained from vehicle to Grid applications. All this makes EVs an expensive and risky purchase, even though the total cost of ownership is probably competitive to that of a regular car. Moreover, EVs produce uncertainty for drivers. The limited battery range and the uncertain availability of chargers make "carefree" driving difficult. These are all problems that will eventually be solved, but nonetheless pose barriers to consumer take-up (for an overview of EV barriers see [1]). There is some momentum for EVs, but it remains a fragile and uncertain venture; the emerging market of EV's can still break down.

Governmental action is one of the possibilities to overcome the problems of an emerging market. There is a wide array of policy-options available to government to support the introduction of EVs and charging infrastructure. Therefore, governmental intervention requires choice; governments wonder which policy to choose, which group or sector to target, what the most effective size and scope of interventions should be, and what timing best accommodates the emerging process of the market. Research into the influence of financial incentives and other socio-economic factors on electric vehicle adoption is currently ongoing (see for instance [2]), and there is research into particular countries (e.g. [3] on the US and [4] for Brazil). Critical studies attack the subsidization of EVs in the short and medium term with tax-payers money [5] whilst other authors calculate differently with social / societal lifetime (e.g. public health and atmospheric pollution) costs and come to more favorable results, depending also on the internalization of the costs by government regulation [6]. Not only are there many options to choose from, there are also many different theories about what to choose for $[7,8,9]$.

Furthermore, some studies reflect on the "best" scale of governance for EV-policy (see e.g. $[10,11])$. For some, and especially in an EU level, the notion of subsidiarity comes in: "the sharing, not shedding, responsibility in the context of a multi-level policy where the policy process straddles supra-national, national, regional and local levels" [12:22]. Hierarchically, there is the level of global agreements, e.g. through the International Energy Agency (IEA), which can drive innovation, collaboration and dissemination $[13,14]$. There is then the level of integrated markets, e.g. with mandatory standards around emissions for vehicles. Then there is the regional (e.g. Electric mobility pilot regions), and not least there is the local level, which again has extra policies. EVpolicy is a multi-level policy game, whereas policy-makers continuously have to take into account and operate within frameworks and actions set elsewhere. Governance is nested, which is to say that the UK or German or Dutch national level cannot be seen separate from the EU level (e.g. see negotiations in the Council of Ministers and the European parliament over emission standards of vehicles), nor can the regional level be seen as disconnected from the national / Federal or international one in terms of investment, competition, standards (including for charging infrastructure), nor can the local one (e.g. air pollution from the EU one). Nested means there is a variance of policy measures for a variety of reasons and motives, and one should learn from each other, whilst being in the same overall framework which influences what one has to address and to some extent the rules of doing so.

There is a growing literature on EV policy at national, and to some extent regional and local level, and now also supra-national level $[15,16$, 17]. However, only some is of a comparative nature, and other than project reports (e.g. [18]) or commissioned consultancy studies (e.g. [19]). There is comparative work that contrasts two or three cases; e.g. [20, 21, 22]. This paper adds to this literature by exploring the policy-options for governments that want to support the further introduction of EVs, and by doing so from a multi-country case-set. 


\section{Scope, Methods, and Limitations}

This research focuses purely on passenger vehicles ${ }^{\mathrm{i}}$ and multipurpose passenger vehicles ${ }^{\mathrm{ii}}$. Furthermore, the present study focuses solely on a specific type of electrified drive trains; of the most commonly used categories - hybrid electric vehicles (HEVs) ${ }^{\mathrm{iii}}$, plug-in hybrid electric vehicles (PHEVs) ${ }^{\mathrm{i}}$ and battery electric vehicles $(B E V s)^{\mathrm{v}}-$ we take into consideration only policies concerning PHEVS and BEVS. Policy for HEVs is not part of the research. Also, we did not look at other possible options for clean mobility, such as bio-fuels, hydrogen, or the substitution of cars for public transport [23].

In order to collect the study's data we gathered all the documents they could find for the seven case-countries in this specific study; the Netherlands, Belgium, Germany, Denmark, Sweden, Norway, and the UK. California is added as a comparative case to contrast the European findings. California is widely regarded as a frontrunner in the transition to e-mobility [24]. To collect the documents a 'snowballing'method was employed to gather more information about policy. Many documents contained references to other studies and sources that we then looked up and included into their model.

The analytical lens we employ is based on, firstly, a value-chain approach to e-mobility [25], which we here arranged into three chains - with interactions and interdependencies of the electric vehicle, the charging infrastructure, and the (wider) enabling network (the grid, Information and Communications Technologies (ICT) and Intelligent Transport Solutions (ITS) and services etc. Secondly, we adopt Hood and Margetts' [26] four different categories of tools for government to "steer", and use these four categories as a first lens to organize the policies. In the table below they explain the categories and apply them to policy for EVs. Thirdly, we looked at policy as originating from one of four levels of government; policy is trans-national, national, regional, or local.

With this first selection of documents we populated our database and ran a first scan of results. For each country, we drafted an analysis of its EV-policies and asked a local resource colleague to take a critical look at the document; they then asked the local colleagues to correct their document and send them links to relevant documents not yet included in the study. We analyzed this second set of documents and improved their country-analysis on the basis of the feedback from the local colleagues. After that, we finalized our findings in a draft-report. During 2013 we kept collecting new documents, in order to be able to keep the database up to date with new policies and new data about performances.

As a third round, we presented and discussed the draft-report in four feedback sessions where expert representatives of the participating countries reflected on their interim findings. Representatives were selected from both the local academic community and the community of EV-policy makers from that country, region, or municipality. In each session, we presented a selection of the findings that were relevant to the particular audience (country). After that, we first asked participants if they recognized or could validate the findings and if they had additions or other (critical) remarks about them. Then, there was time for discussion about the more general implications of the findings and possible implications for policy. Each of the feedback sessions resulted in a general recognition for and support of our findings, but also lead to interesting discussions about methodology and about the dilemmas of policy for EVs.

\section{Outline of this paper}

We start with a presentation of the framework used to analyze policies. After that, we present the assorted variety of policies we found. In the discussion section, we reflect on what we think one can learn from these policies for the next phase in the introduction of e-mobility.

\section{A framework for analyzing $E V$ - policy}

\section{Lens 1: Policy at a certain Level of govern- ment}

As a first lens for our analysis, we looked at policy as originating from one of three levels of government; policy is trans-national, national, regional, or local - with a hierarchy but also interactions between levels and a multilevel governance nature to it, and competition also between countries, regions and cities (cf. 
[10]). Different countries work with different systems, where other levels of government are responsible for e-mobility. The model takes this into account, in order to be able to analyze the differences in various countries. Some organize policy from the local level, while others have a stronger national policy that is only marginally supplemented by local or regional policies.

\section{Lens 2: three Value Chain of E-Mobility}

"EV-policy" suggests a coherent and single object and objective for policy. However, if one looks closer, e-mobility involves a variety of related but separate elements. Therefore, we looked at e-mobility as a value chain $[27,28]$ where the different segments of the chain can each be targeted by policy. Also, e-mobility can be separated into three different value chains; the value chain of vehicles, the value chain of charging, and the value chain of surrounding network. The latter is not so much a chain, but more a third category for policy. For the value chains of vehicles and charging, we see four segments in each chain. Policy can target at least one and possible elements of the chain. For instance, a purchase subsidy targets the vehicles value chain, and within that the consumer-segment. Therefore, we categorize that particular policy as a vehicle-consumerfocused policy in our framework. Figure 1 presents the three value chains; Tables 1 to 3 explain the different segments of the value chains.

Figure 1: Three value chains of e-mobility.

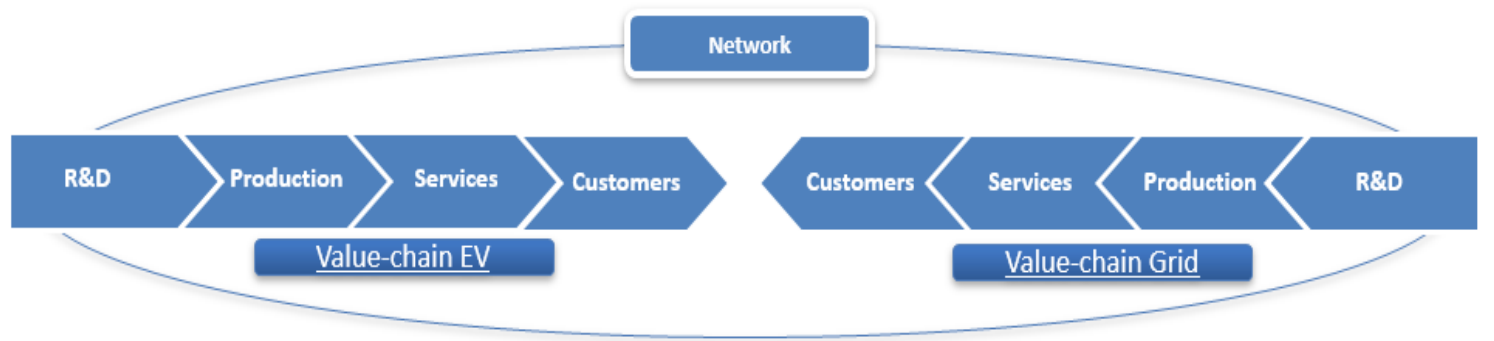

Table 1: Vehicle value chain.

\begin{tabular}{l|ll}
\hline Value chain - electric vehicle \\
\hline R\&D & $\bullet \begin{array}{l}\text { Instruments focused on influencing the research and design of electric vehicles and EV com- } \\
\text { ponents. }\end{array}$ \\
\hline Production & $\bullet \begin{array}{l}\text { Instruments focused on influencing the production of electric vehicles and vehicle compo- } \\
\text { nents such as batteries and other hardware (original equipment manufacturers). This segment } \\
\text { of the value-chain also recognizes the software used in electric vehicles. }\end{array}$ \\
\hline Services & $\bullet \begin{array}{l}\text { Instruments focused on influencing service-providers for electric vehicles. Different service } \\
\text { providers are recognized, such as car dealerships, mechanics, insurance companies, etc. }\end{array}$ \\
\hline Customers & $\bullet \begin{array}{l}\text { Instruments focused on influencing customers of EVs. The study's methodology recognizes } \\
\text { individual consumers (end-users), but also fleet-owners (e.g. authorities and leasing compa- } \\
\text { nies) and public / governmental agencies (promoting consumerism). }\end{array}$ \\
\hline
\end{tabular}

Table 2: Infrastructure value chain.

\begin{tabular}{l|ll} 
Value chain - charging infrastructure \\
\hline R\&D & $\bullet \begin{array}{l}\text { Instruments focused on influencing the research and design of the complete charging infra- } \\
\text { structure. }\end{array}$ \\
\hline Production & $\bullet \begin{array}{l}\text { Instruments focused on influencing the production of charging stations and EV system com- } \\
\text { ponents such as the electricity network, energy production, etc. }\end{array}$ \\
\hline Services & $\begin{array}{l}\text { Instruments focused on influencing service providers for charging stations. Different service } \\
\text { providers are recognized, such as energy suppliers, power plants, grid managers, software de- } \\
\text { velopers, etc. }\end{array}$ \\
\hline Customers & $-\begin{array}{l}\text { Instruments focused on influencing customers of charging-stations. By 'customers' the study } \\
\text { refers both to users (consumers) and owners (consumers, companies, public authorities and }\end{array}$ \\
\hline
\end{tabular}


government). The different types of charging stations (private, public, fast, quick, normal) require different types of steering by governmental units.

Table 3: Network value-chain.

\begin{tabular}{l|ll} 
Value chain - Network & \\
\hline Network & $\begin{array}{l}\text { These are all of the instruments that focus on connecting stakeholders in the EV / infrastruc- } \\
\text { ture value-chain. For instance, efforts intended to intensify contacts between different stake- } \\
\text { holders, in order to improve value-chain alignment and a more efficient functioning of the en- } \\
\text { tire value-chain. In addition to the value-chain, this includes other policy measures aimed at } \\
\text { the e-mobility ecosystem, which are taken into consideration. For instance, policy measures } \\
\text { aimed at realizing Smart Grids, Smart economies and Smart mobility [25] }\end{array}$ \\
\hline
\end{tabular}

Lens 3: Policy as Tools

In their classic tools of government-study Hood and Margetts [26] distinguish four different categories of tools for government to "steer". We use these four categories as a first lens to organize the policies. In Table 4 below we explain the categories and apply them to policy for EV's.

Table 4: Tools of government.

\begin{tabular}{l|ll}
\multicolumn{2}{l}{ Tools of government } \\
Legal & $-\begin{array}{l}\text { All of the rules and directives designed to mandate, enable, incentivize, limit or otherwise } \\
\text { direct subjects to act according to policy goals. }\end{array}$ \\
\hline Financial & $\begin{array}{l}\text { E.g.: legal requirements, local parking legislation, European legislation for standards for } \\
\text { charging-station accessibility, limited access to urban areas or roads. }\end{array}$ \\
& $\begin{array}{l}\text { The policy instruments involve either the handing out or taking away of material resources } \\
\text { (cash or kind), in order to incentivize behavior by subjects. The difference between financial } \\
\text { and legal measures is that those affected are not obliged to take the measures involved, but are } \\
\text { incentivized to do so by their own choice. }\end{array}$ \\
\hline Communication & $\begin{array}{l}\text { E.g.: purchase grants, tax benefits for consumers of EVs, government funding for battery } \\
\text { research, subsidies on home chargers, or free electricity for public charging. }\end{array}$ \\
\hline Organization & $\begin{array}{l}\text { Instruments that influence the value-chain of e-mobility through to the communication of } \\
\text { arguments and persuasion, including information and education. }\end{array}$ \\
& $\begin{array}{l}\text { E.g.: education in schools, government information campaigns. } \\
\text { Actions by government that provides the physical ability to act directly, using its own forces } \\
\text { to achieve policy goals rather than others. This includes the allocation of means, capital, re- } \\
\text { sources, and the physical infrastructure needed to act. } \\
\text { E.g.: government or public authorities acting as a launching customer, buying an own fleet of } \\
\text { EVs, government installing public chargers. }\end{array}$ \\
\hline
\end{tabular}

\section{Findings: an analysis of EV- policies in seven $\mathbf{E U}$ countries}

In this chapter we compare the variety of policies at different governmental levels in different countries. We present our general findings and illustrate them with examples from different countries. The complete results and the total body of policies can be found in the project background report [23].

\section{Finding 1: most NSR countries focus on financial and organizational instruments}

The countries in this collated data set primarily focus on financial and organizational instruments (see Table 5). Most policies fall into either one of those two categories of tools.

As for financial instruments, countries adopt very similar policies. They are often conducted by the national government and are mostly fiscal (registrations bonus based on emissions, income tax measures and opportunities for businesses to relieve the cost of an EV against taxable profits). Also, governments apply a considerable number of organizationalinstruments (see Table 6 for examples). Especially at the regional and local levels we observe a lot of 'organization tools'. Local and 
regional governments - but also some publicprivate partnerships - install many local project organizations that, for instance, carry out grant applications and are launching consumer initiatives. This generates extra dynamics to the incentives and benefits set out by the national government.

The focus on legal and communication instruments is limited compared to financial and organizational instruments.

Table 5: Type of policy actions [23].

\section{Type of policy actions}

\begin{tabular}{|c|c|c|c|c|}
\hline NSR-countries & Legal & Financial & Communicative & Organizational \\
\hline Belgium & - & ++ & - & +++ \\
\hline Denmark & - & +++ & - & ++ \\
\hline Germany & - & ++ & - & +++ \\
\hline Netherlands & - & +++ & - & +++ \\
\hline Norway & ++ & +++ & - & ++ \\
\hline Sweden & - & ++ & - & +++ \\
\hline UK & 0 & ++ & - & ++ \\
\hline California & ++ & +++ & - & - \\
\hline $\begin{array}{lll}0 & =\text { Limit } \\
- & =\text { Limit } \\
++ & =\text { Stron } \\
+++ & =\text { Preva }\end{array}$ & $\begin{array}{l}\text { formation } \\
\text { cus } \\
\text { us } \\
\text { focus area }\end{array}$ & able & & \\
\hline
\end{tabular}

Table 6: Examples of organizational tools used in different countries.

\section{Organizational incentives in NSR countries, and California (USA)}

\begin{tabular}{|c|c|}
\hline Denmark & $\begin{array}{l}\text { Platform: } \\
\text { - Information Centre. In cooperation with the Danish Energy Agency, the Centre for Green } \\
\text { Transport has established (Established in2011) an information centre to exchange experienc- } \\
\text { es on EV's between local communities in Denmark [29,30,31]. } \\
\text { Project organization: } \\
\text { - Copenhagen Electric. Copenhagen Electric focuses on strengthening the capital region's } \\
\text { international competitiveness and ensuring greater cooperation in the Øresund Region and } \\
\text { other regions in Europe by providing objective information about electric vehicles to munici- } \\
\text { palities, companies and private individuals. Also projects, campaigns and partnerships on } \\
\text { EVs are initiated [32]. }\end{array}$ \\
\hline Germany & $\begin{array}{l}\text { Project organization: } \\
\text { - Model regions: } \\
\text { E.g. Elektromobilitat Model Region Hamburg. The testing of diesel hybrid buses on } \\
\text { lines; innovative energy storage for rail vehicles; the use and development of EVs and } \\
\text { charging infrastructure; the use of EVs in commercial traffic (BMVI Elektromobilitat } \\
\text { Model Region, 2014). } \\
\text { E.g. Model region Bremen/Oldenburg. The model region Bremen/Oldenburg applies } \\
\text { cooperation between partners such as the University of Bremen, Bremer Energie Institut } \\
\text { and Centre for Regional and Innovation Economics. The local Daimler/Mercedes pro- } \\
\text { duction plant uses the knowledge to produce new technologies [33], }\end{array}$ \\
\hline
\end{tabular}

\section{Finding 2: Most NSR-countries initiate policy from the national government level}

As summarized in Table 7, in most countries most policy is made at the national level. However, with that said, there are often also very active local and regional communities that provide all sorts of activities to stimulate emobility. The main body of policy is national fiscal, regulation - but that is accompanied by local and regional policy that provides a local coloring and fine-tuning.
Table 7: Government level of EV policy [23].

\begin{tabular}{|l|l|l|l|}
\hline Government level \\
\hline Country & National & Regional & Local \\
\hline Belgium & - & +++ & - \\
\hline Denmark & - & +++ & +++ \\
\hline Germany & +++ & ++ & - \\
\hline Netherlands & ++ & ++ & ++ \\
\hline Norway & +++ & - & - \\
\hline Sweden & +++ & - & - \\
\hline UK & +++ & ++ & - \\
\hline California & ++ & ++ & ++ \\
\hline $0 \quad=$ Limited information found / available \\
$-\quad$ Limited focus \\
\hline
\end{tabular}


$++\quad=$ Strong focus

$+++\quad=$ Prevalent focus area

\section{Finding 3: In most NSR-countries policy} focuses on vehicles rather than charging

Policy instruments mostly focus on the vehicle-value chain (see Table 8). Within the EVvalue chain, governments primarily focus policy on consumers. Some countries focus more prominently in $R \& D$ and on upstream segments. Little attention is given to the segment of services, which could be a missing link between the demand of consumers and the supply provided by manufacturers.

Table 8: Policy focus on the vehicle value chain [23].

\section{Policy focus in the EV-value chain}

\begin{tabular}{|l|l|l|l|l|}
\hline Country & $\begin{array}{l}\text { R\& } \\
\text { D }\end{array}$ & $\begin{array}{l}\text { Produc- } \\
\text { tion }\end{array}$ & $\begin{array}{l}\text { Ser- } \\
\text { vices }\end{array}$ & $\begin{array}{l}\text { Cus- } \\
\text { tomer }\end{array}$ \\
\hline Belgium & - & - & - & ++ \\
\hline Denmark & +++ & 0 & - & ++ \\
\hline Germany & +++ & ++ & - & +++ \\
\hline $\begin{array}{l}\text { Nether- } \\
\text { lands }\end{array}$ & - & ++ & - & +++ \\
\hline Norway & ++ & - & - & +++ \\
\hline Sweden & ++ & - & - & ++ \\
\hline UK & ++ & - & - & ++ \\
\hline California & +++ & ++ & - & ++ \\
\hline $\begin{array}{l}0 \\
-\quad=\text { Limited information found / available } \\
++\quad=\text { Limited focus } \\
+++\quad \text { Strong focus } \\
+7\end{array}$ Prevalent focus area \\
\hline
\end{tabular}

\section{Finding 4: Policy mostly targets the} downstream of the vehicle value chain

Most countries focus downstream in the vehicles value chain. They adopt a large number of financial incentives, at different government levels (tax incentives, rebates, subsidies, local benefits, etc.). In Denmark, one-third of the steering instruments in the EV value chain focus on consumers. Different levels of government implement downstream policies. Subsidies and tax incentives are usually implemented at national level. However, local governments also provide financial incentives, often cash but mostly 'in-kind'. Examples are free or preferential parking, access to toll lanes, free charging, free access to ferries for EVs. At first glance, these are small incentives. However, their impact should not be overlooked. In a recent Californian survey 59\% of the respondents indicated that access to the high-occupancy vehicle lane (HOV-lane) was extremely or very important in their decision to purchase an EV, making it the most important motivator for purchase found in the survey [34].

Although countries mostly focus downstream (some work more upstream (R\&D and production). Most of these instruments are financial (see Table 10 on the next page for examples). Germany focuses strongly on R\&D in EV policy, which can be explained by the presence of major vehicle manufacturers in Germany. However, Sweden also has a strong focus on $R \& D$. Over one-third of the policy instruments found in Sweden focuses on stimulating R\&D. In France, Renault partners with the CEA (French Alternative Energies and Atomic Energy Commission) to work on electric vehicles. Compared to the European cases, California is very upstream (mostly R\&D) focused [23].

Table 9: Examples of downstream financial instruments for vehicles targeting consumers [23].

\begin{tabular}{|l|l|}
\hline Examples: Financial incentives - downstream, consumer focused) \\
\hline lands & $\begin{array}{l}\text { Tax incentives: } \\
\text { EV's are exempt from the registration tax and from the annual road tax. Fuel cell EVs follow the } \\
\text { same ruling. }\end{array}$ \\
$\begin{array}{l}\text { For leased cars, an income tax measure makes EVs and HEVs attractive. A normal tariff of } 25 \% \\
\text { of a leased car's value that is added to the annual income tax is eliminated (7\% from 2014) for } \\
\text { zero-emission cars (less than } 50 \mathrm{~g} \text { CO2/km) or will be } 14 \% \text { or } 20 \% \text { according to the fuel type and } \\
\text { CO2 emissions if the cars are fuel-efficient. } \\
\text { Tax relief regulation for purchasing commercial electric vehicles. } \\
\text { Through the MIA and VAMIL regulation of the central government, entrepreneurs can receive a } \\
\text { subsidy for purchasing an EV or installing charging infrastructure. } \\
\text { Rebates / subsidies: } \\
\text { The city of Amsterdam grants subsidies up to 5.000 Euros to purchase EVs which are being used }\end{array}$ \\
\hline
\end{tabular}




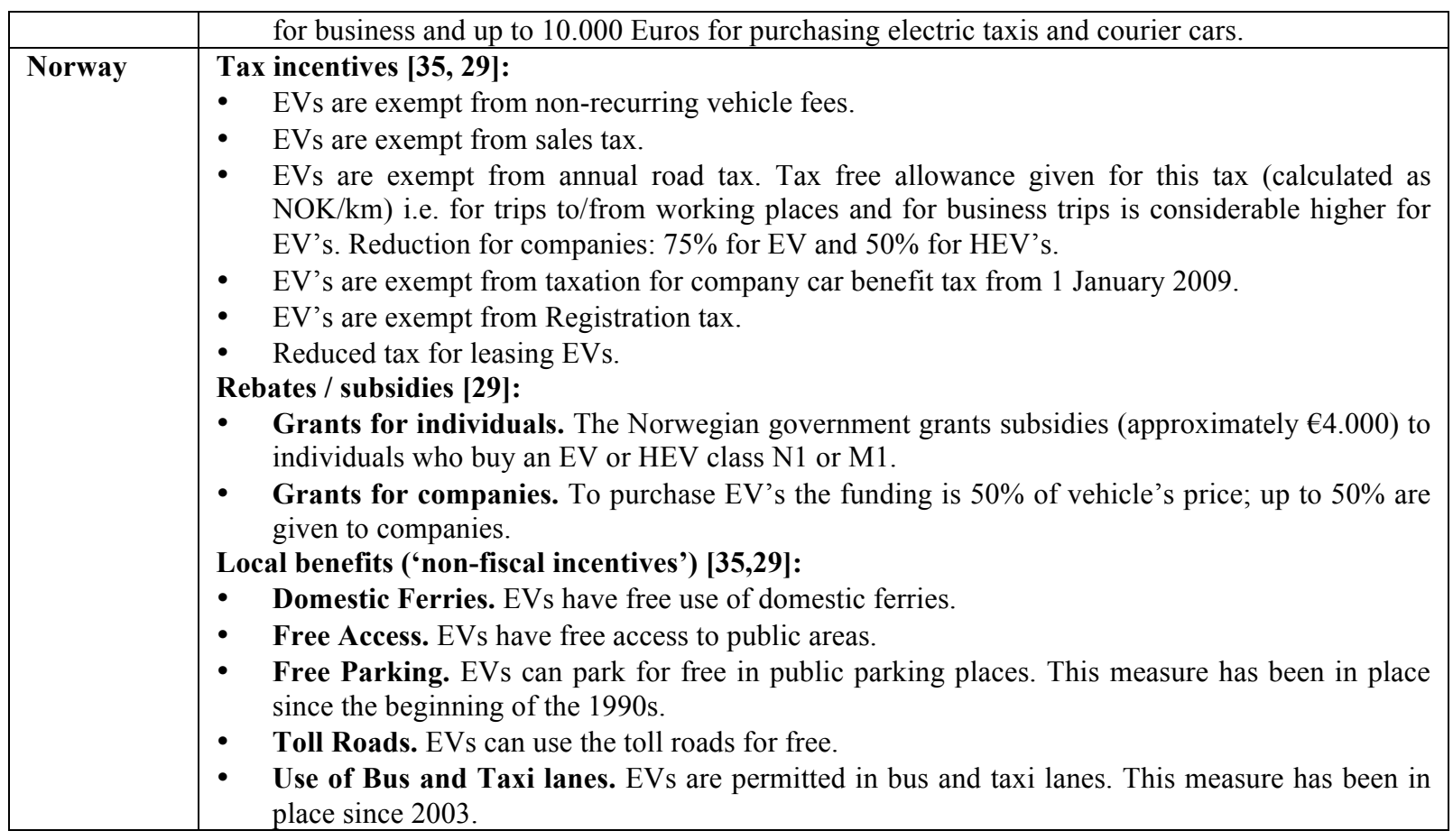

Table 10: Examples of upstream financial incentives for vehicles [23].

\begin{tabular}{|l|l|}
\hline Financial incentives - upstream of the value chain (R\&D and production focused) \\
\hline Germany & $\begin{array}{l}\text { Research funding: } \\
\text { - }\end{array}$ \\
& $\begin{array}{l}\text { The storage battery program is founded to build capacities in Germany for implementation } \\
\text { throughout the whole supply chain in the production of storage batteries. The program runs } \\
\text { from } 2009 \text { until 2012, and the Federal government has granted } 35 \text { million Euros to this pro- } \\
\text { gram. } \\
\text { The third mobility and transport research program (BMWI) sets out the goals, for instance to } \\
\text { research into drive technology. Special importance is attached to developing new vehicle } \\
\text { concepts and technologies for reducing energy consumption and pollution by road transport. } \\
\text { Through the BMBF ICT } 2020 \text { research for innovation, EENOVA receives } 100 \text { million Euros } \\
\text { for research on energy management in EV's. } \\
\text { The Lithium-ion battery alliance is a project to substantially increase the energy and perfor- } \\
\text { mance density of lithium ion batteries and to accelerate the possible use in production. The } \\
\text { Federal government has granted } 60 \text { million Euros to this project. }\end{array}$ \\
\hline
\end{tabular}

Finding 5: Few countries focus on charging infrastructure. Also, policy in the infrastructure value chain focuses less on downstream and targets the upstream segments.

In the infrastructure value chain, the focus upstream can be explained by the relatively large number of policies that focus on the installation of (semi)-public charging points (mostly by regional and local governments). Many of those instruments focus on the installation of (semi-) public charging points. Studies show that most EV charging currently takes place at home [36]. For instance, the UK national government initiated from 2009 onwards the PIP (Plugged-In-Places) program. It in- tended to support the development and consumer uptake of ultra-low carbon vehicles by introducing electric-car hubs in six key British cities. Compared to the European cases, California has a lot of rebate/subsidy instruments which focus on the installation of a charging infrastructure. A lot of which are focused on home-chargers.

Table 11 shows the focus in policy for the charging infrastructure value chain.

Table 11: Policy focus in the infrastructure value chain [23].

Policy focus in the charging infrastructure value chain

\begin{tabular}{|l|l|l|l|l|} 
Country & $\begin{array}{l}\text { R\& } \\
\text { D }\end{array}$ & $\begin{array}{l}\text { Produc- } \\
\text { tion }\end{array}$ & $\begin{array}{l}\text { Ser- } \\
\text { vices }\end{array}$ & $\begin{array}{l}\text { Cus- } \\
\text { tomer }\end{array}$ \\
\hline
\end{tabular}




\begin{tabular}{|c|c|c|c|c|}
\hline Belgium & 0 & - & ++ & ++ \\
\hline Denmark & ++ & - & - & ++ \\
\hline Germany & ++ & ++ & - & - \\
\hline $\begin{array}{l}\text { Nether- } \\
\text { lands }\end{array}$ & - & +++ & - & - \\
\hline Norway & + & ++ & - & ++ \\
\hline Sweden & ++ & - & - & - \\
\hline UK & - & ++ & ++ & ++ \\
\hline California & - & ++ & - & +++ \\
\hline $\begin{array}{ll}0 & = \\
- & = \\
++ & = \\
+++ & =\end{array}$ & \multicolumn{4}{|c|}{$\begin{array}{l}=\text { Limited information found / available } \\
=\text { Limited focus } \\
=\text { Strong focus } \\
=\text { Prevalent focus area }\end{array}$} \\
\hline
\end{tabular}

\section{Discussion}

Our study finds that EV policy captured here mainly target the vehicle value chain. Also, most countries target the downstream segments (consumers). Policy hardly takes into account services.

Within this category of downstream oriented policy, most tools are financial. For EV's three types of financial downstream incentives most common: tax incentives, rebates, and specific local extra benefits for EV-owners (e.g. free parking). The Netherlands has many incentives that target lease drivers, which presents an interesting sub-group for policy to focus on. Only a few countries focus explicitly on charging. Moreover, policies for charging mostly focus upstream.

Given the current phase in the introduction of EV's, the emphasis on financial instruments is understandable. The purchase price of an EV and charger are high and this will withhold many from having one. Downstream financial instruments can overcome these barriers and were probably the crucial factor for the rather successful early penetration of EV's in the market; downstream financial policies have been the backbone of the early market phase of EVs [23, 37]. However, if we take into account the exponential growth in the numbers of sales required for the next phase in the introduction, this policy strategy quickly becomes unsustainable [37]. The exponential growth of the next phase of the introduction of EVs requires a self-enforcing loop in the sales of EV, and cannot rely on government policy to 'push' sales by means of very strong direct incentives. Policy should become oriented at initiating, sustaining, and perhaps even the management of such self-sustaining loops [37]. This calls for a different kind of policies that should be reflected in a different policy strategy for the design of future programs; not the piling up of large enough incentives for consumers and industry, but policies that mix together to help instigate a societal dynamics towards EV's. Not only does this raise questions about the type of measures that fit such a mixed policy strategy, but also about the level of government that is best equipped to lead it. Designing and maintaining a patchwork of policymeasures to sustain and steer societal dynamics requires local knowledge about real time developments in the system, and that suggests a more prominent role for local and regional government. Policy still remains nested in a multi-level framework, but local and regional governments could very well become the leading level for the next generation of policy; within a framework of national (fiscal) policy, and supra-national standards, but with local measures to keep the momentum in the local development going. This is a break from the current patterns in EV-policy making, and we are seeing early indicators for it emerging [37]. Furthermore, we think that a next generation EV-policy cannot be without a reignited political debate about the costs and benefits of EV's, and the time-horizon for these to be achieved. Already, countries' resources and public support are overstretched and there is growing societal pressure to downsize financial stimuli. As the quantity of vehicles grows, governments have to look for other tools to stimulate the market for EV's, and this will require political debate.

Government policy greatly contributed to the first small but significant steps on the path towards full-scale introduction of e-mobility; however, policy-makers will need a different strategy and different policy tools to further the next step in the introduction. This study displays and reviews the policies made to support the small first steps, now policies have to be developed that support the giant leap. 


\section{Acknowledgments}

The paper is part of the Interreg e-mobility North Sea Region (E-Mobility NSR) partnership project, which is co-funded by the EU and participating countries / regions / organizations.

\section{Bibliography}

[1] Beeton, D. and Butte, B. (2013). Future of Markets for Electric Vehicles. Expectations, Constraints \& Long-Term Strategies. Report of a roadmapping workshop facilitated by Urban Foresight for the International Energy Agency Hybrid \& Electric Vehicle Implementing Agreement and the Austrian Institute of Technology. April 2013.

[2] Sierzchula, W.; Bakker, S.; Maat, K. and Wee, B. van, (2014). The influence of financial incentives and other socioeconomic factors on electric vehicle adoption, Energy Policy, Vol. 68, Issue C, pp. 183-194.

[3] Green, E. H, Skerlos, S.S. and Winebrake, J.J. (2014). Increasing electric vehicle policy efficiency and effectiveness by reducing mainstream market bias, Energy Policy, Vol. 65, Feb. 2014, pp. 562-566

[4] Domingues, S. M. and Pecorelli-Peres, L.A. (2013). Electric vehicles, energy efficiency, taxes, and public policy in Brazil, Law and Business Review of the Americas, Vol. 19, Issue No 1, pp. 55-78.

[5] Prud'homme, R. and Konig, M. (2012). Electric vehicles: A tentative economic and environmental evaluation, Transport Policy, Volume 23, September 2012, pp. 60-69.

[6] Funk, K. and Rabi, A. (1999). Electric versus conventional vehicles: social costs and benefits in France, Transportation Research Part D: Transport and Environment, Vol. 4, Issue 6, November 1999, pp. 397-411.

[7] Van der Steen, M., P. van Deventer, J.A. de Bruijn, M.J.W. van Twist, E. ten Heuvelhof, K.E. Haynes, Zhenhua Chen, Governing Innovation: The Transition to EMobility-A Dutch Perspective. Paper presented at the AAG Annual Meeting, Paper Session 'Electric Vehicles', on Saturday 25 February 2012, in NY, NY.

[8] Van Deventer, A.P., M. Van der Steen, J.A. De Bruijn, E.P. Ten Heuvelhof, K.E.
Heynes, Governing the transition to emobility: small steps towards a giant leap, Netherlands School of Public Administration, The Hague, 2011.

[9] Browne, D; .O'Mahony, M. and Caulfield, B. (2012). How should barriers to alternative fuels and vehicles be classified and potential policies to promote innovative technologies be evaluated?, Journal of Cleaner Production, 35, pp. 140-151.

[10] Bakker, S. (2014) Momentum for Electric Mobility - Dynamics of multi-level governance. Presentation at conference "Electric Vehicles and Eco Cars: Solutions for Green Growth", 11 April 2014, 9-5pm, London Metropolitan University, UK.

[11] Bakker, S.; Maat, L. and Trip, J.J. (2014). Transition to electric mobility: spatial aspects and multi-level policy-making. Project report NSR E-mobility network.

[12] Flynn, A. and Morgan, K. (2004). Governance and Sustainability. Chap 2, pp. 2139, In: Thomas, M. And Rhisiart, M. (eds) Sustainable Regions. Making Sustainable Development Work in Regional Economies. Aureus Publishing Ltd.: Vale of Glamorgan.

[13] IEA IA-HEV (2011). International Energy Agency, Electric Vehicles Initiative . Hybrid and Electric Vehicles. The Electric Drive Plugs in. Implementing Agreement for co-operation an Hybrid and Electric Vehicle Technologies and Programmes. www.ieahev.org.

[14] IEA IA-HEV (2012). International Energy Agency, Electric Vehicles Initiative . EV City Casebook.

[15] Bakker, S. (2013) Standardization of EV Recharging Infrastructures. Report written within the framework of Activity 4.4 of the Interreg IVB project E-Mobility NSR. December 2013.

[16] Kotter, R. (2013). The developing landscape of electric vehicles and smart grids: a smart future?, International Journal of Environmental Studies, 70 (5). pp. 719-732.

[17] Loisel R.; Passaoglu, G. and Thiel, C. (2014). Large-scale deployment of electric vehicles in Germany by 2030: An analysis of grid-to-vehicle and vehicle-to-grid concepts, Energy Policy, Vol. 65, Feb. 2014, pp. 432-443. 
[18] Trip, J.J.,Lima, J. and Bakker, S. (2012) Electric mobility policies in the North Sea Region countries. Project report NSR emobility.

[19] E4Tech (2013). Low Carbon Vehicles in the North East - Economic Impact Study. Final Reportfor North East Local Enterprise Partnership Board, 11th September 2013. Newcastle upon Tyne / London.

[20] Yang, C.-Y. (2012). Launching strategy for electric vehicles: Lessons from China and Taiwan, Technological Forecasting and Social Change, Vol. 77, Issue 5, June 2010, pp. 831-834.

[21] Karplus, V.J.; Paltsev, S. and Reilly, J.M. (2010.) Prospects for plug-in hybrid electric vehicles in the United States and Japan: A general equilibrium analysis, Transportation Research Part A: Policy and Practice, Vol. 44, Issue 8, October 2010, pp. 620641.

[22] Steinhilber, S; Wells, P; Thankappan, S (2013). Socio-technical inertia: Understanding the barriers to electric vehicles, Energy Policy, Volume 60, September 2013, pp. $531-539$.

[23] Van der Steen, M..; Van Schelven, R.; Mulder, J. \& Van Twist, M. (2014). Introducing e-mobility: Emergent strategies for an emergent technology. Ambition, Structure, Conduct and Performance. Background report. The Hague: Dutch School for Public Administration (NSOB). Available at: http://e-mobility-nsr.eu/infopool/

[24] Plugincars. (2013). Six Bills That Would Ensure California's Electric Car Future: Plugincars. (2013). Six Bills That Would Ensure California's Electric Car Future: http://www.plugincars.com/six-billswould-ensure-californias-ev-future128410.html

[25] Beeton, D. (2012) Electric Vehicle Cities of the Future: A Policy Framework for Electric Vehicle Ecosystems. Urban Foresight. Newcastle upon Tyne.

[26] Hood, C. and Margetts, H. (2007). The Tools of Government in the Digital Age. Second edition. Basingstoke: Palgrave Macmillan.

[27] Fournier, G. and Stinson, M. (2011). The Future Thinks Electric. Developing an electric mobility value chain as a foundation for a new energy paradigm, Interdisciplinary Management Research, Vol. 7: 867.

[28] Squarewise (2010) Elektrisch Rijden: internationale stand van zaken. (English E-mobility: international overview). For the Ministry of Economic Affairs in The Netherlands.

[29] Bakker, S.; Lima J. and Trip. J.J. (2012). Electric mobility policies in North Sea Region countries. NSR E-mobility project report. Technical University of Delft, The Netherlands. Available at: http://e-mobilitynsr.eu/fileadmin/user_upload/downloads/inf o-pool $/ 3.3$ - E-

mobility policies in the NSR countries.pdf.pdf

[30] European Commission (2011). Ecoinnovation Action Plan. Danish green transport plan to get the environment back on track. Available at: http://ec.europa.eu/environment/ecoap /about-eco-innovation/policiesmatters/denmark/388_en.html

[31] IEA IA-HEV (2014). International Energy Agency, Electric Vehicles Initiative. The International Energy Agency (IEA) Hybrid \& Electric Vehicle Implementing Agreement. Available at: http://www.ieahev.org/by-country/demarkon-the-road-and-deployments/

[32] Copenhagen Electric (2014). The Regional EV Secretariat. Available at: http://www.cph-electric.dk/

[33] BMVI - Elektromobilitat Model Region Hamburg (2014): http://www.hamburg.de/pressearchiv-fhh/

[34] CCSE (2014). Center for Sustainable Energy California. February 2014 PEV Owner Survey Report. See:

http://energycenter.org/clean-vehiclerebate-project/vehicle-owner-survey/feb2014-survey

[35] WSDOT (2011). Electric Vehicle Policies, Fleet, and Infrastructure: Synthesis. Available at: http://www.wsdot.wa.gov/NR/rdonlyre s/5559AE0E-8AB5-4E6B-8F8BDE-

AA7ECE715D/0/SynthesisEVPoliciesFlee tandInfrastructureFINALRev112911.pdf

[36] Snyder, J.; Chang, D.; Erstad, D.; Lin, E.; Falkan Rice, A..; Tzun Goh, C. and Tsao, A.A. (2012). Financial Viability of Non- 
Residential Electric Vehicle Charging Stations. UCLA Luskin Center for Innovation.

[37] Van der Steen, M., R. van Schelven, D. Bressers \& J. Mulder (2014). One step at a time: a complexity perspective for the next generation of EV-policy, The Hague, NSOB. Available at: http://e-mobilitynsr.eu/info-pool/

[38] IEA IA-HEV and AVERE (2013). International Energy Agency, Electric Vehicles Initiative and AVERE (2013) Global EV Outlook 2013. International Energy Agency, Electric Vehicles Initiative. http://www.iea.org/publications/globalevou tlook 2013.pdf

\section{Authors}

Martijn van der Steen is Associate-Dean of The Netherlands School of Public Administration (NSOB) in The Hague, The Netherlands. Martijn holds a $\mathrm{PhD}$ in Public Administration from Tilburg University, a Master in Public Administration and a Master in History.

Peter Van Deventer is Program Director of the Coast-to-Coast E-Mobility Program at the Consulate General of The Netherlands in San Francisco, CA, USA. He holds a PhD in Engineering from Ohio State University, and a Master in Public Administration from the Netherlands School of Public Administration.

Rogier van Schelven is a Senior-Consultant at Dutch consultancy firm Kwink Group, located in The Hague, The Netherlands.

Mark van Twist is a Professor of Public Administration at Erasmus University Rotterdam, in Rotterdam, The Netherlands. He is also dean and member of the board of the Netherlands School of Public Administration, and extraordinary member of the board of the Netherlands Court of Audit.

Richard Kotter is a Senior Lecturer in Economic and Political Geography at Northumbria University in Newcastle, UK. Richard is interested in regional economic development in border regions, ecological modernization and environmental transformations, and urban futures.

\section{Endnotes}

Vehicle with a designated seating capacity of 10 or less [38].

ii Vehicle with a designated seating capacity of 10 or less that is constructed either on a truck chassis or with special features for occasional off-road operation [38].

iii HEV has the ability to operate all-electrically, generally at low average speeds. At high steady speeds such a HEV uses only the engine and mechanical drivetrain, with no electric assist. At intermediate average speeds with intermittent loads, both electric and mechanical drives frequently operate together. [13].

iv A HEV with a battery pack with a relatively large amount of $\mathrm{kWh}$ of storage capability, with an ability to charge the battery by plugging a vehicle cable into the electricity grid [13].

$\checkmark$ An BEV is defined as "any autonomous road vehicle exclusively with an electric drive, and without any onboard electric generation capability" [13]. 